\title{
ГДЕ СВЯЗЫВАЮТСЯ ПОТЕНЦИАЛЬНЫЕ ИНГИБИТОРЫ RBD SARS-COV-2?
}

\section{С.С. Борисевич', Э.М. Хамитов', М.А. Гуреев², О.И. Яровая³ , Н.Ф. Салахутдинов ${ }^{3}$}

${ }^{1}$ Лаборатория химической физики, Уфимский институт химии УФИЦ РАН, 450074, Россия, Уфа, пр. Октября, 71.

2Лаборатория биоинформатики, Первый МГМУ им. Сеченова, 119991, Россия, Москва, ул. Большая Пироговская, 2-4.

${ }^{3}$ Отделение медицинской химии, Новосибирский институт органической химии СО РАН, 630090, Россия, Новосибирск, пр. Академика Лавреньтева, 9.

DOI: 10.19163/MedChemRussia2021-2021-219

E-mail:monrel@mail.ru

Для поиска потенциальных ингибиторов рецептор-связывающего домена S-белка SARS-CoV-2 практически всегда рассматривается интерфейс связывания RBD и ACE-2. Спайк белок связывается своим RBD с ACE-2 с высоким сродством. Предполагается, что потенциально активная молекула может связываться в зоне контакта RBD и ACE-2 и, как следствие, изменить структурную гибкость белка [1]. Однако возникает вопрос: может ли активная молекула связываться в другом месте домена и, оказывая влияние на вторичную структура белка, ослабевать связывание домена с ферментом? Возможно ли участие не одной, а нескольких молекул в процессе ингибирования домена? Для ответа на эти вопросы мы создали ряд молекулярных моделей, включающих домен и комплекс домен-фермент, и провели ряд молекулярно-динамических симуляций в присутствии различного количества молекул арбидола. Арбидол был выбран в качестве вероятного ингибитора на основании данных [2]. Нами определялись возможные места связывания потенциальных ингибиторов и оценивалась степень влияния молекул арбидола на структурную гибкость протеина.

A

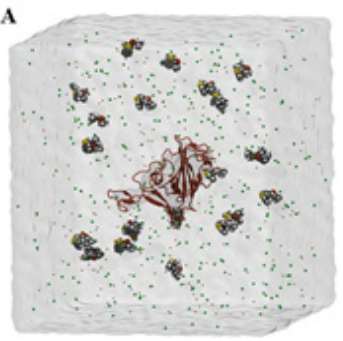

B

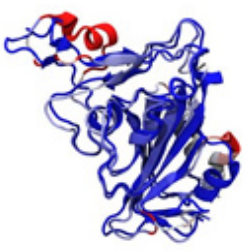

C

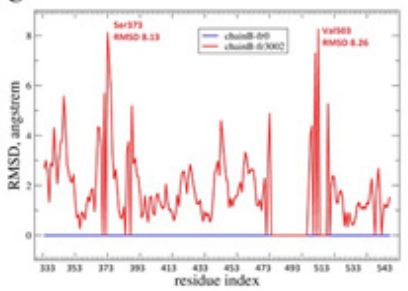

Рис. 1. Молекулярная модель:

A - стартовая система RBD и 20 молекул арбидола, точками представлены $\mathrm{Na}^{+} \mathrm{u} \mathrm{Cl}^{-}$;

B - изменение вторичной структуры домена в течении процедуры молекулярнодинамической симуляции, красным цветом выделены наиболее драматические изменения; C - колебания значений RMSD аминокислотных остатков домена.

Работа выполнена при финансовой поддержке Российского фонда фундаментальных исследований в рамках проекта № 20-04-60038

\section{Литература}

[1] A.K. Padhi et al., Eur. J. Pharm. 2021, 894, 173836.

[2] Xi Wang et al., Cell Discovery. 2020, 6 (28), 1-5.

$$
-219-
$$

